\title{
Parallel Class Ranking Model Using Analytic Hierarchy Process With Multi Criteria
}

\author{
Model Perangkingan Kelas Paralel Menggunakan Analitic Hierarchy Process dengan \\ Multi Kriteria
}

Received:

14 October 2019

Revised:

15 December 2019

Accepted:

26 January 2020

\author{
${ }^{1 *}$ Dedy Hidayat Kusuma, ${ }^{2}$ Moh. Nur Shodiq, ${ }^{3}$ Indah Kurnia \\ Fitriani \\ ${ }^{1,2,3}$ Teknik Informatika, Politeknik Negeri Banyuwangi \\ ${ }^{1,2,3}$ Banyuwangi, Indonesia \\ E-mail: ${ }^{1}$ dedy@poliwangi.ac.id, ${ }^{2}$ noer.shodiq@poliwangi.ac.id, \\ indahkurnia40@gmail.com
}

*Corresponding Author

\begin{abstract}
Madrasah Aliyah Negeri (MAN) Banyuwangi using a worksheet which can lead to error occurrences and slow decision making. A system for decision support that can improve the ranking process and quality were developed in this paper. The proposed system implemented the codeigniter framework, MySQL database, and PHP programming language. The system provided three user roles which are teacher, student, and administrator role. These four parameters are used as ranking system input, including academic values, non-academic values, violation scores, and student attendance. The ranking process was conducted by applying the analytic hierarchy process (AHP) method. The developed decision support system was tested using two ways: the black box testing method and providing questionnaires. Black box testing result shows that the system has functionally worked, while user's questionnaire gives $92,29 \%$ well accepted by users. The results show that the decision support system can help manage values and determine the parallel ranking list.
\end{abstract}

Keywords - parallel ranking, analytic hierarchy process, MAN Banyuwangi

Abstrak-Madrasah Aliyah Negeri (MAN) Banyuwangi menggunakan pemeringkatan dengan worksheet sehingga dapat menimbulkan kesalahan dan lambatnya proses pengambilan keputusan. Dari permasalahan tersebut maka dikembangkan suatu sistem pendukung keputusan yang dapat memudahkan proses penentuan peringkat dengan cepat dan berkualitas. Sistem ini dibangun menggunakan codeigniter framework, basis data MySQL, dan bahasa pemrograman PHP. Sistem menyediakan hak akses untuk tiga jenis pengguna yakni guru, siswa, dan admin. Parameter yang digunakan sebagai dasar perangkingan yaitu nilai akademik, nilai non-akademik, skor pelanggaran, dan kehadiran siswa. Proses perangkingan selanjutnya dilakukan menggunakan metode analytic hierarchy process (AHP). Pengujian terhadap sistem yang dikembangkan menggunakan dua metode yaitu black box dan kuesioner. Hasil pengujian black box menunjukkan sistem telah berfungsi dengan baik, sedangkan hasil kuesioner memberikan nilai akhir 92,29\% dapat diterima dengan baik oleh pengguna. Dari hasil tersebut dapat disimpulkan bahwa sistem pendukung keputusan ini dapat membantu pengelolaan nilai dan penentuan daftar peringkat paralel.

Kata Kunci_perangkingan paralel, analytic hierarchy process, MAN Banyuwangi

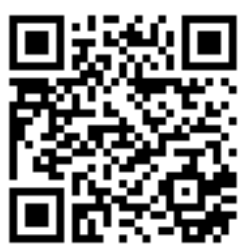




\section{INTRODUCTION}

Class assessments are conducted by teachers to measure the achievement and development of students' learning processes towards the achievement of learning goals and mastery of competencies [1]. The results of the assessment are then used to determine student achievement. Schools that have many study groups in the same class usually also use a parallel ranking model. At the Banyuwangi Aliyah State Madrasah (MAN), high school (SMA) level schools under the auspices of the Indonesian Ministry of Religion, value processing and parallel achievement ranking in this school still use conventional systems that use worksheets. With a total of 1,003 students and 31 classes, manual classification results in error vulnerability and a slow ranking process. The primary ranking that has been running so far also only uses academic grades for the ranking of high achieving students. Ranking by including non-academic values will provide a more comprehensive picture of the assessment results [2]. On the other hand, schools also need a system that can manage student grade data properly.

To overcome the problems that have been described, a decision support system is needed to determine computerised academic and non-academic achievements that can later produce quality decisions. The system is built using the analytic hierarchy process (AHP) approach model. AHP method can be used to help the decision-making process of complex problems that have several alternative solutions to obtain the best resolution to resolve the issue. Some users of AHP in decision support systems in education include evaluating teacher performance [3], school selection [4], [5], student career development [6], scholarship determination [7], [8], and commitment of interest and majors [9]. AHP implementation for student ranking has also been carried out [10] but only using one-class data, and Z-Score is used as methods that provide a standardised value based on the deviation value and the average of each criterion

Parallel student ranking system is built using the code igniter framework by applying the AHP method. This system is equipped with academic and non-academic value storage features as an essential feature of ranking. With this system, it is expected that the decision-making process of school academic achievement will be faster and more accurate.

\section{RESEARCH METHOD}

In the research conducted, a web-based application system built that provides an interface to enter grades, set parameters and processing, and to display the results of the system output in the form of student rankings. Implementation of the AHP approach used as a method for 
INTENSIF, Vol.4 No.1 February 2020

ISSN: 2580-409X (Print) / 2549-6824 (Online)

DOI: https://doi.org/10.29407/intensif.v4i1.13769

ranking students. While developing system or software applications as a whole using the waterfall method of software development models. The waterfall method in Figure 1 shows the development of a system that is carried out sequentially step by step from requirements analysis, planning, modelling, development to system implementation [11], [12].

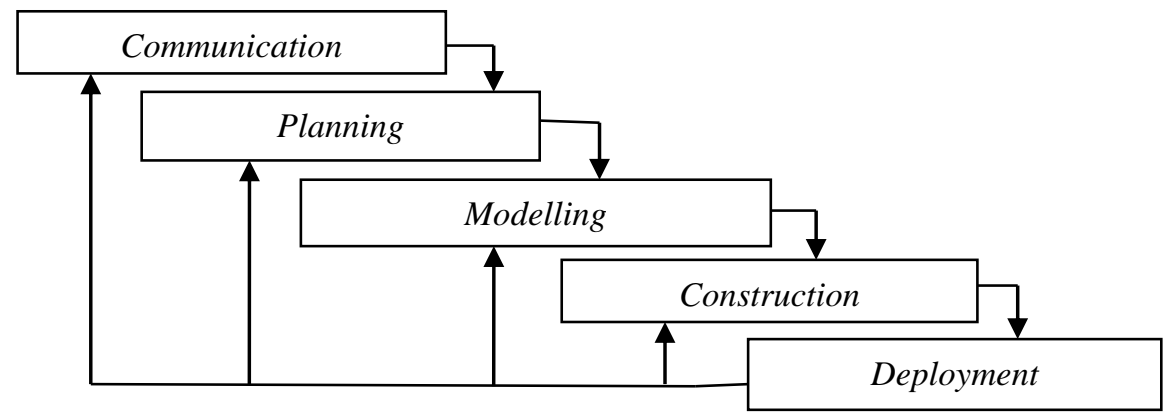

Figure 1. WATERFALL METHOD

\section{A. Research Data}

This research data collection method is done through interviews with the school and direct data collection. Interviews conducted with all parties relating to the system, including students, teachers, the administration department, and elements of school management. While direct data retrieval is done by collecting related documents and direct observation of activities related to the problem [13]. The data obtained are grouped into two parts :

1. Primary data, i.e. data used to derive the criteria used in the process of ranking the AHP method includes:

Academic Value is the value taken from the benefits of subjects in MAN Banyuwangi. The subjects can be shown in Table 1 .

Table 1. SUBJECTS

\begin{tabular}{|c|c|}
\hline Major & $\overline{\text { Subject }}$ \\
\hline Religion & $\begin{array}{l}\text { English, Cross-Interest Economics, Hadith Science, Al-Hadith, Interpretation, } \\
\text { Mathematics, Indonesian Language, SKI, Kalam Science, Usul Fiqh, Cultural Arts, } \\
\text { Health, Physical Education, Arabic Language Pmt, Entrepreneurship, Pkn, moral } \\
\text { theology, Fiqh, Indonesian History, Morals. }\end{array}$ \\
\hline Science & $\begin{array}{l}\text { Mathematics, Hadith Science, Fiqh, Al Quran Hadith, Language and Literature Cross } \\
\text { Interests, Chemistry, English, Physical Education, Physics, Indonesian Language, } \\
\text { Moral Creed, Mathematics Pmt, Civic Education, Physics, Biology, Culture, Islamic } \\
\text { culture history, Arabic Language. }\end{array}$ \\
\hline Social & $\begin{array}{l}\text { Cultural Arts, Islamic Morals, Indonesian Language, Mathematics, Economics, Cross- } \\
\text { Interest English Literature, Sociology, English, History, Islamic culture history, } \\
\text { Entrepreneurship, Physical Education, Quran Hadith, Geography, Indonesian History, } \\
\text { Civic Education, Fiqh, Arabic. }\end{array}$ \\
\hline Language & $\begin{array}{l}\text { Entrepreneurship, Japanese Language and Literature Specialization, Physical } \\
\text { Education, Indonesian Language and Literature, Fiqh, Indonesian History, } \\
\text { Anthropology, English Language and Literature Specialization, Cultural Arts, Arabic } \\
\text { Language, Indonesian Language, Aqeedah moral, Al Quran Hadith, English Language, }\end{array}$ \\
\hline
\end{tabular}


Non-Academic Value is the value of student self-development, which is included in achievements outside of school activities, required how active students are in participating in this activity. The extracurricular activities at MAN Banyuwangi are listed in Table 2.

Table 2. EXTRACURRICULAR

\begin{tabular}{cc}
\hline \hline No. & Extracurricular \\
\hline 1 & Soccer \\
\hline 2 & Futsal \\
\hline 3 & Scout \\
\hline 4 & Nature lovers \\
\hline 5 & PMR (Youth Red Cross) \\
\hline 6 & Rohis (Rohani Islam) \\
\hline 7 & Volleyball \\
\hline 8 & Basketball \\
\hline
\end{tabular}

Attendance is the amount of attendance inside and outside the class. In one semester there are 156 school days active (not including holidays). The value of violations are points of violation of the Madrasah code of conduct. The weight of violations to the order is determined based on the policies in force in Banyuwangi State Aliyah Madrasah.

2. Complementary data contained additional information related to teachers, students, classes and majors in MAN Banyuwangi, namely Religion, Sciences, Social, and Languages with 1003 students and 31 classes.

\section{B. AHP Ranking}

Flowchart for the calculation process using the AHP method is shown in Figure 2. First the admin gives the initial value of the criteria that have been determined in the form of academic, non-academic, absenteeism, and violation. After that, the admin enters data from each criterion. Then the system makes a matrix of values by comparing each of the specified criteria, then doing the eigenvector calculation. After getting the results of calculating the consistency index, then the consistency ratio. If the consistency ratio is not consistent, then repeat it from the initial determination of the weights in the criteria. If it is consistent, then calculate the results of the eigenvector criteria and eigenvector sub-criteria then produce a ranking list result. 
INTENSIF, Vol.4 No.1 February 2020

ISSN: 2580-409X (Print) / 2549-6824 (Online)

DOI: https://doi.org/10.29407/intensif.v4i1.13769

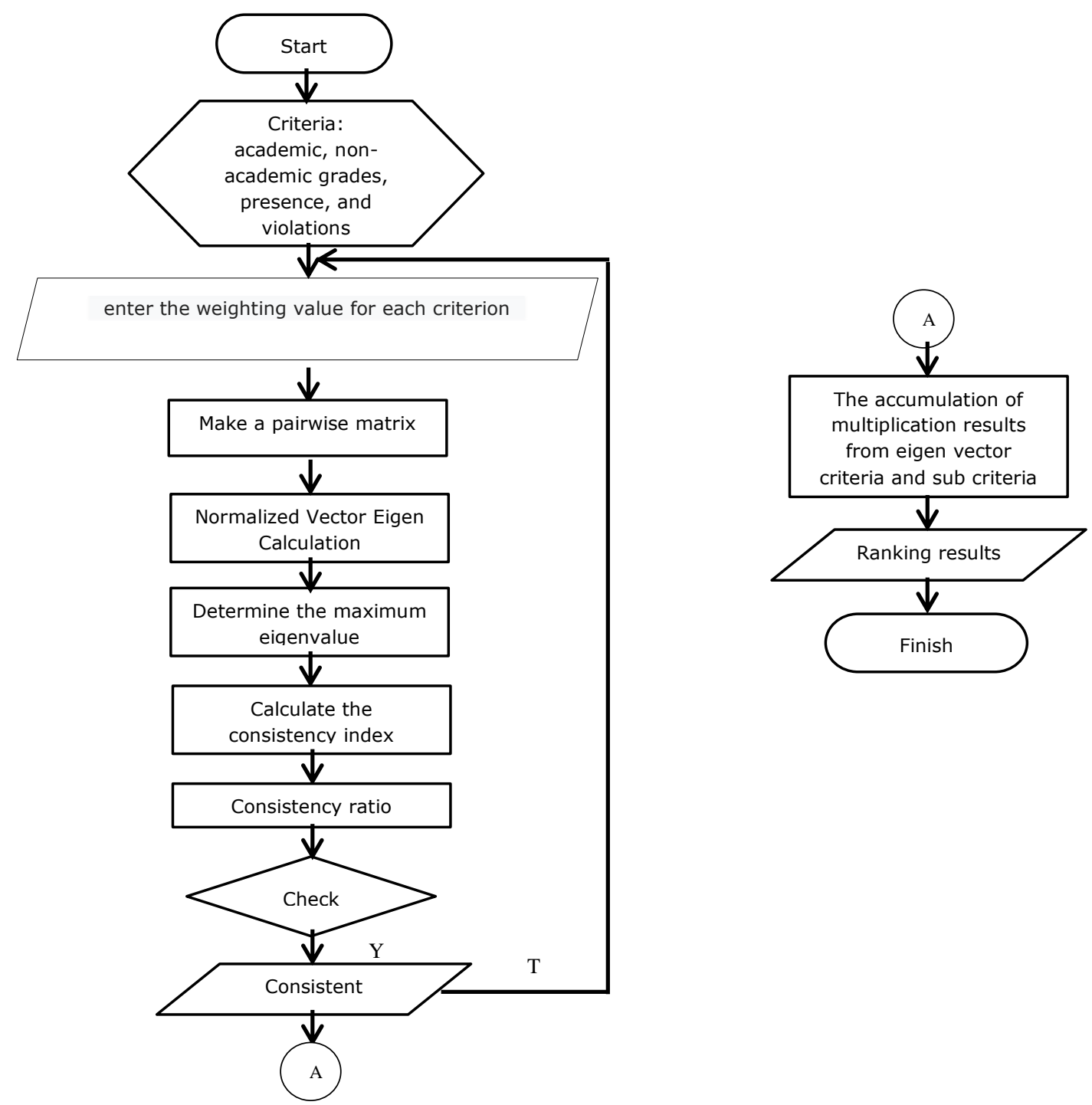

Figure 2. FLOWCHART SYSTEMS FOR LEARNING DECISIONS

Following is an example of calculation based on Figure 2 using the Analytic Hierarchy Process method according [14], [15] in parallel class ranking:

1. Establish criteria and sub-criteria and alternatives viz: Academic Value, Non-Academic Value, Attendance, and Violation.

2. Determining sub-criteria can be shown in Table 3. 
INTENSIF, Vol.4 No. 1 February 2020

ISSN: 2580-409X (Print) / 2549-6824 (Online)

DOI: https://doi.org/10.29407/intensif.v4i1.13769

3. Arrange the pairwise Comparison criteria matrix by comparing the ratings of each existing criterion. Comparative assessment of each measure is carried out by the school according to applicable regulations - Pairwise comparate criteria matrix shown in Table 4.

Table 3. SUB CRITERIA

\begin{tabular}{ll}
\hline \hline Academic Value & $\begin{array}{l}\text { Very good (3499-3200), good (3299-3000), good enough (2999- } \\
\text { 2800), enough (2799-2600), bad (2599-2400). }\end{array}$ \\
\hline $\begin{array}{l}\text { Non-Academic Value } \\
\text { (extracurricular achievements) }\end{array}$ & Very good (A), good (B), good enough (C), good (D), bad (E). \\
\hline Attendance & $\begin{array}{l}\text { Very good (144-139), good (138-133), good enough (132-127), } \\
\text { sufficient (126-121), bad (120-115). }\end{array}$ \\
\hline Violation & $\begin{array}{l}\text { Very good (0), good (0-20), good enough (20-30), enough (30- } \\
50), \text { bad (50-100) }\end{array}$ \\
\hline
\end{tabular}

Table 4. MATRIX OF PAIRWISE COMPARISON

\begin{tabular}{lcccc}
\hline \hline & Violation & Attendance & $\begin{array}{c}\text { Non- } \\
\text { Academic }\end{array}$ & Academic \\
\hline Violation & 1 & 2 & 4 & 6 \\
\hline Attendance & $1 / 2$ & 1 & 3 & 5 \\
\hline Non-Academic & $1 / 4$ & $1 / 3$ & 1 & 4 \\
\hline Academic & $1 / 6$ & $1 / 5$ & $1 / 4$ & 1 \\
\hline
\end{tabular}

4. Change the pairwise comparison criteria matrix to decimal numbers and add up each column of criteria, as shown in Table 5.

Table 5. MATRIX OF PAIRWISE COMPARISON DESIMAL

\begin{tabular}{lcccc}
\hline \hline & Violation & Attendace & $\begin{array}{c}\text { Non- } \\
\text { Academic }\end{array}$ & Academic \\
\hline Violation & 1 & 2 & 4 & 6 \\
\hline Attendance & 0.5 & 1 & 3 & 5 \\
\hline Non-Academic & 0.25 & 0.333 & 1 & 4 \\
\hline Academic & 0.166 & 0.2 & 0.25 & 1 \\
\hline Total & 1.916 & 3.533 & 8.25 & 16 \\
\hline
\end{tabular}

5. Normalise all values by dividing each element per column by the total number of columns, as shown in Table 6 .

Table 6. NORMALISED CRITERIA MATRIX

\begin{tabular}{lcccc}
\hline \hline & Violation & $\begin{array}{c}\text { Attendan } \\
\text { ce }\end{array}$ & $\begin{array}{c}\text { Non } \\
\text { Academic }\end{array}$ & Academic \\
\hline Violation & 0.522 & 0.566 & 0.485 & 0.375 \\
\hline Attendance & 0.261 & 0.283 & 0.364 & 0.313 \\
\hline Non-Academic & 0.130 & 0.094 & 0.121 & 0.250 \\
\hline Academic & 0.087 & 0.057 & 0.030 & 0.063 \\
\hline
\end{tabular}

INTENSIF: Jurnal Ilmiah Penelitian dan PenerapanTeknologi Sistem Informasi 
INTENSIF, Vol.4 No.1 February 2020

ISSN: 2580-409X (Print) / 2549-6824 (Online)

DOI: https://doi.org/10.29407/intensif.v4i1.13769

Table 7. CALCULATION OF EGGEN VECTOR NORMALIZATION

\begin{tabular}{lcccccc}
\hline \hline & Violation & $\begin{array}{c}\text { Attenda } \\
\text { nce }\end{array}$ & $\begin{array}{c}\text { Non } \\
\text { Academic }\end{array}$ & Academic & $\begin{array}{c}\text { Line } \\
\text { Total }\end{array}$ & $\begin{array}{c}\text { Eigen vektor } \\
\text { Normalization }\end{array}$ \\
\hline Violation & 0.522 & 0.566 & 0.485 & 0.375 & 1.946 & 0.486 \\
\hline Attendance & 0.261 & 0.283 & 0.364 & 0.313 & 1.218 & 0.304 \\
\hline Non-Academic & 0.130 & 0.094 & 0.121 & 0.250 & 0.595 & 0.148 \\
\hline Academic & 0.087 & 0.057 & 0.030 & 0.063 & 0.234 & 0.058 \\
\hline
\end{tabular}

6. Calculate normalised eigenvectors by adding up each row and dividing by the number of criteria, as shown in Table 7.

7. Calculate the consistency ratio:

- Calculate the highest eigenvalue $(\lambda \max )$

Done by adding up the results of the multiplication values in Table 5 with the values in Table 7.

$$
\lambda=(1,916 * 0.486)+(3,533 * 0.304)+(8,25 * 0.148)+(16 * 0.058)=4.154
$$

- Calculate the consistency index (CI)

$$
\mathrm{CI}=\frac{\lambda m a k s-n}{n-1}=\frac{4.154-4}{4-1}=0.051
$$

- Consistency ratio

$\mathrm{RC}=$ there are 4 criteria, the value is 0.90

$\mathrm{CR}=\frac{C I}{R C}=\frac{0.051}{0.90}=0.045$

$\mathrm{CR}<0.100$ then the weighting preference is consistent

8. Form a Pairwise Comparison sub-criteria matrix by conducting a comparison assessment of each sub-criterion. The Pairwise Comparate sub-criteria matrix is shown in Table 8.

Table 8. PAIRWISE COMPARISONSUB MATRIX CRITERIA

\begin{tabular}{cccccc}
\hline \hline & Very Good & Good & Pretty Good & Enough & Bad \\
\hline Very good & 1 & 2 & 3 & 4 & 5 \\
\hline Good & $1 / 2$ & 1 & 2 & 3 & 4 \\
\hline Pretty good & $1 / 3$ & $1 / 2$ & 1 & 2 & 3 \\
\hline Enough & $1 / 4$ & $1 / 3$ & $1 / 2$ & 1 & 2 \\
\hline Bad & $1 / 5$ & $1 / 4$ & $1 / 3$ & $1 / 2$ & 1 \\
\hline
\end{tabular}

9. Change the matrix sub-criteria pair comparison into decimal numbers and add each column to the sub-criteria, as shown in Table 9.

Table 9. DECIMAL SUB CRITERIA MATRIC

\begin{tabular}{cccccc}
\hline \hline & Very Good & Good & $\begin{array}{c}\text { Pretty } \\
\text { Good }\end{array}$ & Enough & Bad \\
\hline Very good & 1 & 2 & 3 & 4 & 5 \\
\hline Well & 0.5 & 1 & 2 & 3 & 4 \\
\hline Pretty good & 0.333 & 0.500 & 1 & 2 & 3 \\
\hline
\end{tabular}


INTENSIF, Vol.4 No.1 February 2020

ISSN: 2580-409X (Print) / 2549-6824 (Online)

DOI: https://doi.org/10.29407/intensif.v4i1.13769

\begin{tabular}{cccccc}
\hline \hline Enough & 0.250 & 0.333 & 0.500 & 1 & 2 \\
\hline Bad & 0.200 & 0.250 & 0.333 & 0.500 & 1 \\
\hline Total & 2.283 & 4.083 & 6.833 & 10.500 & 15 \\
\hline
\end{tabular}

10. Normalise all values by dividing each element per column by the total number of columns, as shown in Table 10.

Table 10. NORMALIZED MATRIX SUB CRITERIA

\begin{tabular}{cccccc}
\hline \hline & Very Good & Good & Pretty Good & Enough & Bad \\
\hline Very good & 0.438 & 0.489 & 0.439 & 0.300 & 0.333 \\
\hline Well & 0.219 & 0.244 & 0.292 & 0.285 & 0.266 \\
\hline Pretty good & 0.145 & 0.122 & 0.146 & 0.190 & 0.200 \\
\hline Enough & 0.109 & 0.081 & 0.073 & 0.095 & 0.133 \\
\hline Bad & 0.087 & 0.061 & 0.048 & 0.047 & 0.066 \\
\hline
\end{tabular}

11. Calculate the normalized eigenvector by adding up each row and dividing it by the number of criteria as the results in Table 11.

Table 11. CALCULATION OF EIGEN VECTOR NORMALIZATION

\begin{tabular}{cccccccc}
\hline \hline Very Good & Good & $\begin{array}{c}\text { Pretty } \\
\text { Good }\end{array}$ & Enough & Bad & $\begin{array}{c}\text { Number of } \\
\text { Rows }\end{array}$ & $\begin{array}{c}\text { Eigen Vector } \\
\text { normalization }\end{array}$ \\
\hline Very good & 0.438 & 0.489 & 0.439 & 0.300 & 0.333 & 2.079 & 0.415 \\
\hline Well & 0.219 & 0.244 & 0.292 & 0.285 & 0.266 & 1.306 & 0.261 \\
\hline Pretty good & 0.145 & 0.122 & 0.146 & 0.190 & 0.200 & 0.803 & 0.160 \\
\hline Enough & 0.109 & 0.081 & 0.073 & 0.095 & 0.133 & 0.491 & 0.098 \\
\hline Bad & 0.087 & 0.061 & 0.048 & 0.047 & 0.066 & 0.309 & 0.061 \\
\hline
\end{tabular}

12. Calculate the consistency ratio:

- Calculate the highest eigenvalue ( $\lambda$ maks)

Done by adding up the results of the multiplication values in the table with the values in

Table 11.

$\lambda=(2.283 * 0.415)+(4.083 * 0.261)+(6.833 * 0.16)+(10.5 * 0.098)+(15 * 0.061)=$

\subsection{8}

- Calculate the consistency index (CI)

$\mathrm{CI}=\frac{\lambda \text { maks }-n}{n-1}=\frac{5.050388-5}{5-1}=0.012$

- Consistency ratio

$\mathrm{RC}=$ there are 5 criteria, the value is 1.12

$\mathrm{CR}=\frac{C I}{R C}=\frac{0.012}{1.12}=0.01$

Because $\mathrm{CR}<0.100$ the weighting preferences are consistent

INTENSIF: Jurnal Ilmiah Penelitian dan PenerapanTeknologi Sistem Informasi 
INTENSIF, Vol.4 No.1 February 2020

ISSN: 2580-409X (Print) / 2549-6824 (Online)

DOI: https://doi.org/10.29407/intensif.v4i1.13769

13. Finally, determine the ranking of alternatives by calculating the eigenvector for each criterion and sub-criterion. The weight value is obtained from the conditions owned by the alternative. The value of the violation is 0 (very good) then it is given a weight 1 . Attendance 156 (very good) then it is given a weight 1 . Non-academic B (good) then given a weight 4 . And academic 1530 (very good) then given a weight 1 . Ahmad, the value of the violation 45 (enough), then given a weight 4 . Attendance 138 (good) then given a load 2. Non-academic A (very good) then given a weight 1 . And academic 1565 (very good) then given influences 1 . Results are obtained from the multiplication of the criteria vector, as shown in Table 12.

Table 12. RANKING RESULTS

\begin{tabular}{lccccc}
\hline \hline \multicolumn{1}{c}{ Name } & Violation & Attendance & $\begin{array}{c}\text { Non- } \\
\text { Academic }\end{array}$ & Academic & Result \\
\hline Rino & 1 & 1 & 1 & 1 & 0.41334 \\
\hline Dian & 1 & 1 & 3 & 1 & 0.37560 \\
\hline Caca & 1 & 2 & 1 & 1 & 0.36652 \\
\hline Aulia & 1 & 1 & 4 & 1 & 0.36642 \\
\hline Budi & 1 & 2 & 3 & 2 & 0.31985 \\
\hline Roni & 1 & 3 & 2 & 1 & 0.31303 \\
\hline Rina & 3 & 1 & 1 & 2 & 0.28048 \\
\hline Budi & 2 & 2 & 1 & 3 & 0.27689 \\
\hline Deni & 2 & 3 & 1 & 1 & 0.26098 \\
\hline Ahmad & 4 & 2 & 1 & 1 & 0.21246 \\
\hline
\end{tabular}

\section{RESULTS AND DISCUSSION}

\section{A. System Design}

The system design compiled in this study uses a use case diagram and entity relationship diagram. Use case diagram illustrates the functionality in a parallel ranking decision support system [16] as shown in Figure 4.

Figure 3 shows an overview that takes place on a student ranking list decision supports web system. Students can see student info and ranking list if they have logged in and have been registered by the admin. Homeroom can manage academic and non-academic grades if they are logged in and have been recorded in the admin database. Admin can manage the user, manage the values that have been entered by the homeroom teacher and can run a decision support system when logged in to the system. 
INTENSIF, Vol.4 No. 1 February 2020

ISSN: 2580-409X (Print) / 2549-6824 (Online)

DOI: https://doi.org/10.29407/intensif.v4i1.13769

Entity Relationship Diagram (ERD) is a diagram that shows objects and relationships between objects using identity and relationship [17]. ERD web decision support list of student rankings is shown in Figure 3.

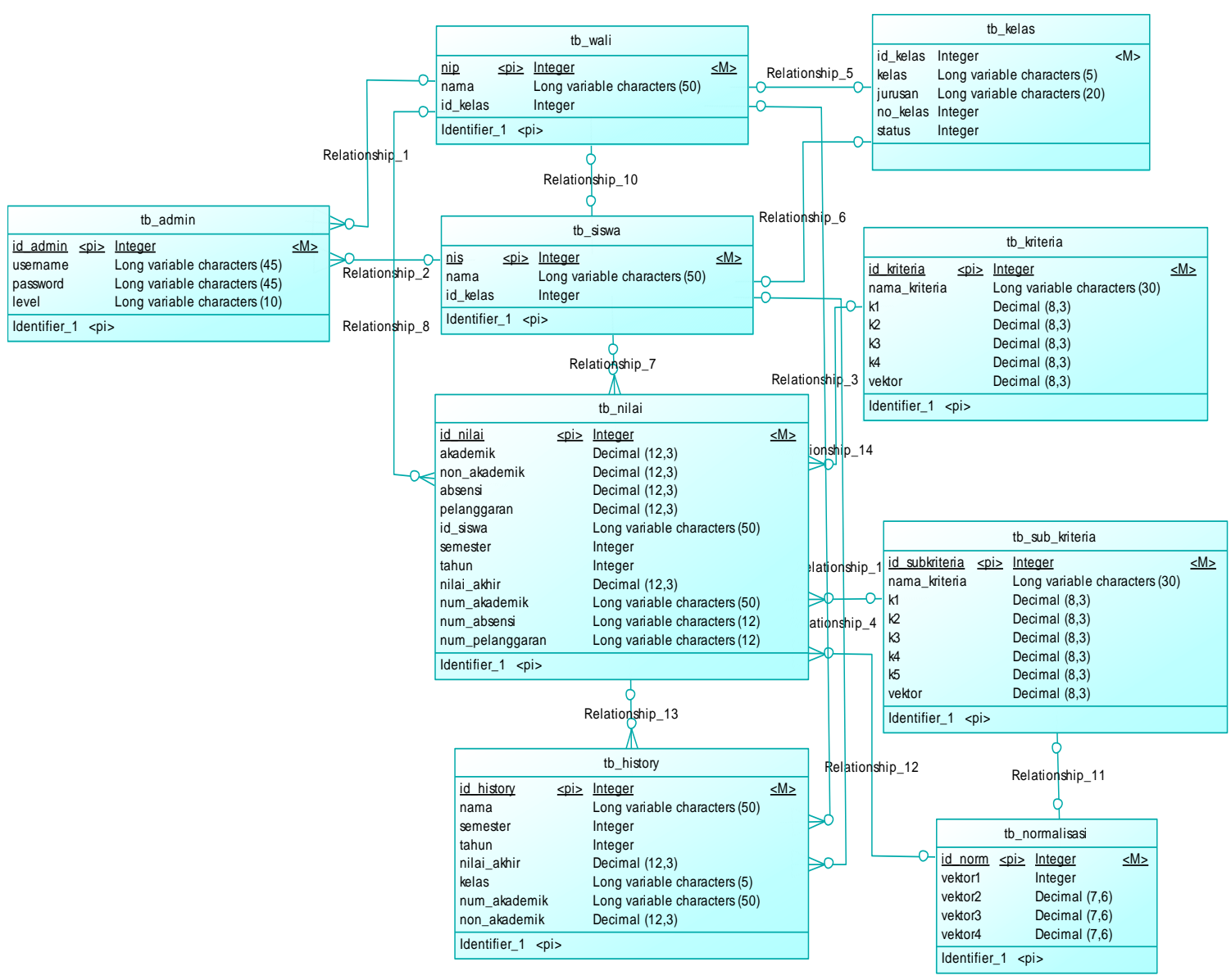

Figure 3.ERD SYSTEM

\section{B. Implementasi Sistem}

To be able to access the support system of parallel ranking decision, all users are required to $\log$ in according to their user name and password. After the admin has logged in, the admin home page will be displayed, as shown in Figure 5.

INTENSIF: Jurnal Ilmiah Penelitian dan PenerapanTeknologi Sistem Informasi 
INTENSIF, Vol.4 No.1 February 2020

ISSN: 2580-409X (Print) / 2549-6824 (Online)

DOI: https://doi.org/10.29407/intensif.v4i1.13769

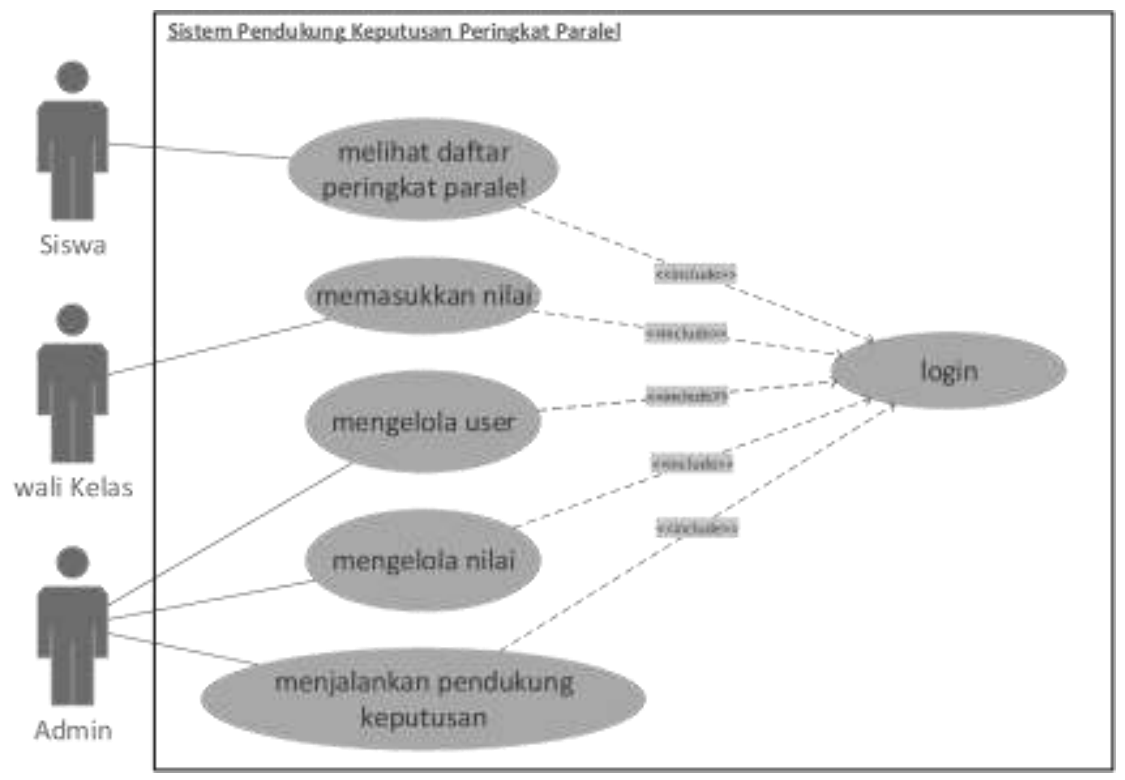

Figure 4. USE CASE DIAGRAM SYSTEM

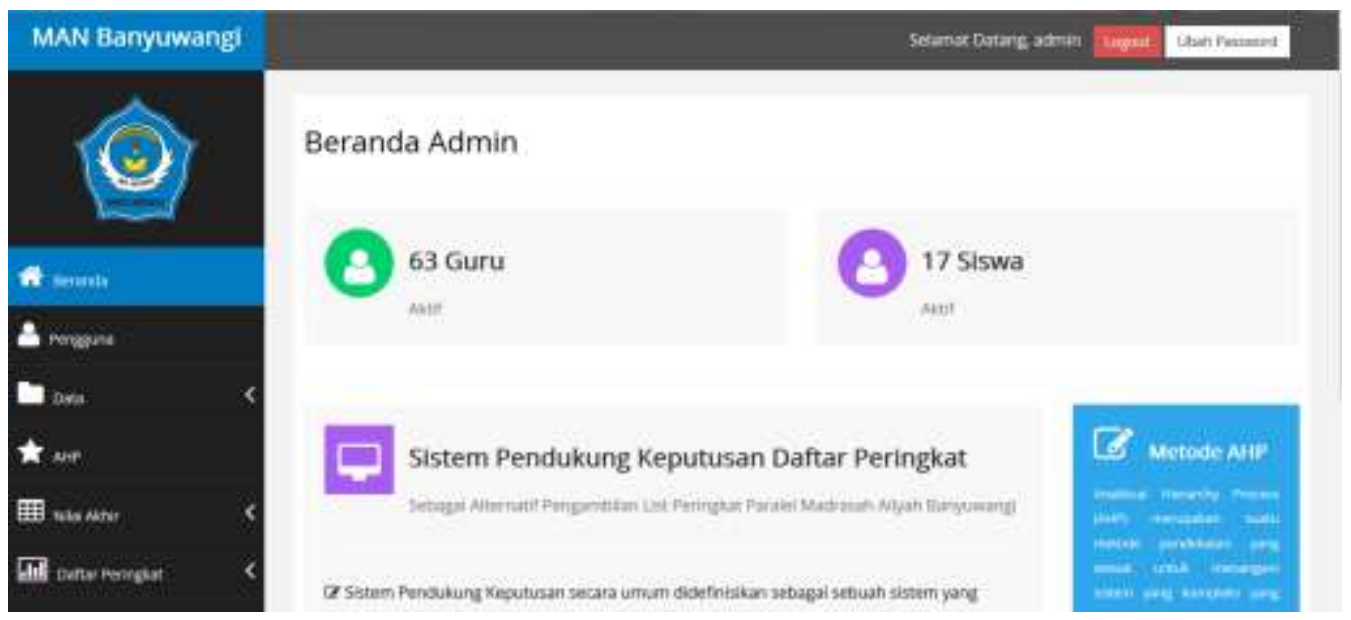

Figure 5. HOME ADMIN

On the admin homepage, there are the Users, Data, AHP, Final Value, and Ranking Lists menus. The user page is useful for managing accounts that contain registered user information, setting levels, and passwords of users shown by Figure 6 .

100 INTENSIF: Jurnal Ilmiah Penelitian dan Penerapan Teknologi Sistem Informasi 
INTENSIF, Vol.4 No.1 February 2020

ISSN: 2580-409X (Print) / 2549-6824 (Online)

DOI: https://doi.org/10.29407/intensif.v4i1.13769

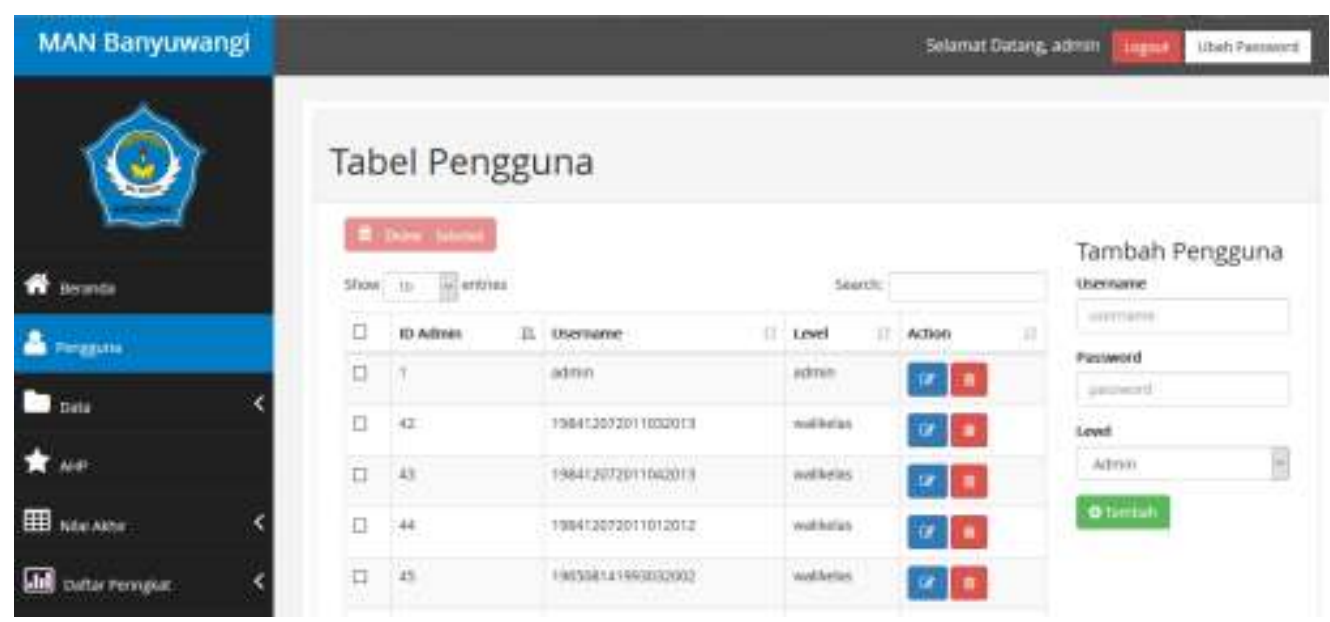

Figure 6. USER PAGE

The Data menu has three submenus, namely class data, student data, and homeroom data. The class data page is used to manage and display class information in the Banyuwangi MAN school, shown in Figure 7.

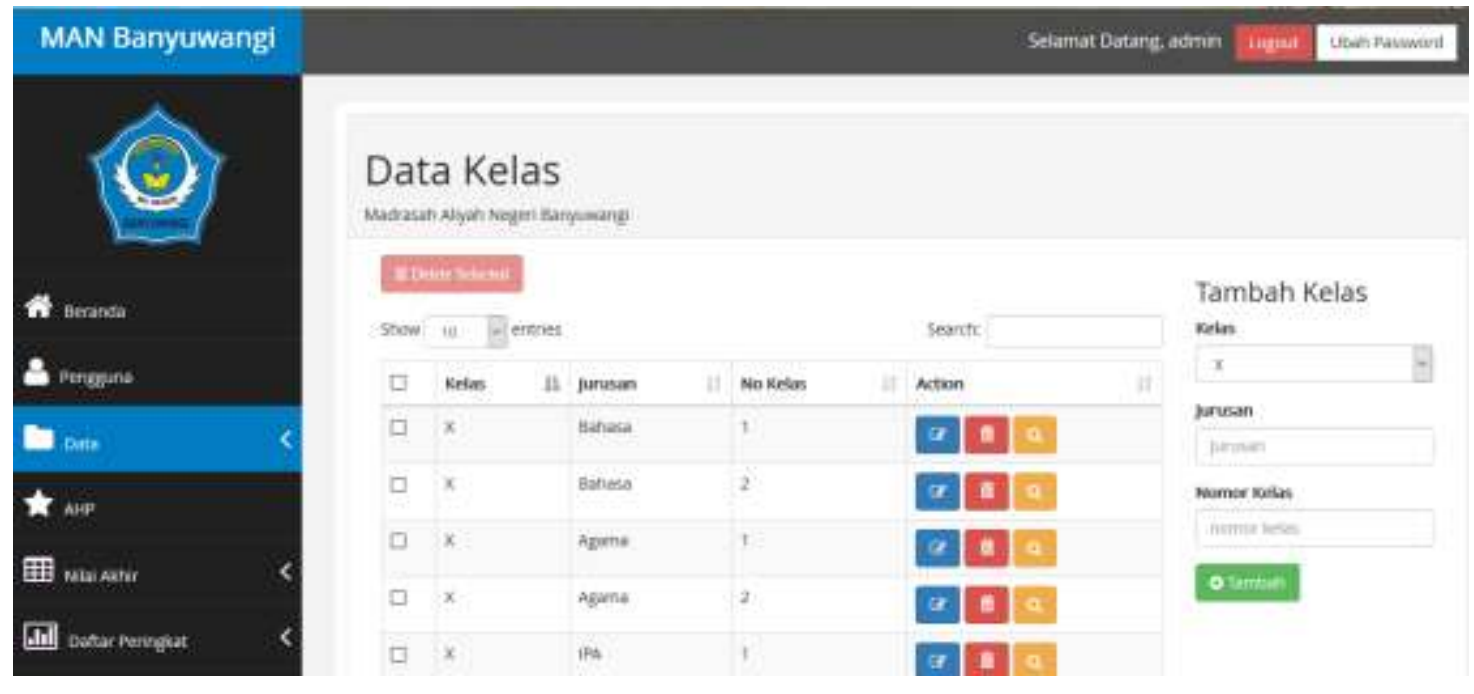

Figure 7. CLASS DATA DISPLAY

The student data page is used to manage and display student information in the Banyuwangi MAN school such as the Student Identification Number, name of the student, and a class of students, which is shown in Figure 8. Whereas the homeroom data page is used to manage and display the information of the homeroom teacher in MAN Banyuwang schools such as Employee Main Number, name of homeroom teacher, and homeroom class as shown in Figure 9.

INTENSIF: Jurnal Ilmiah Penelitian dan PenerapanTeknologi Sistem Informasi 
INTENSIF, Vol.4 No.1 February 2020

ISSN: 2580-409X (Print) / 2549-6824 (Online)

DOI: https://doi.org/10.29407/intensif.v4i1.13769

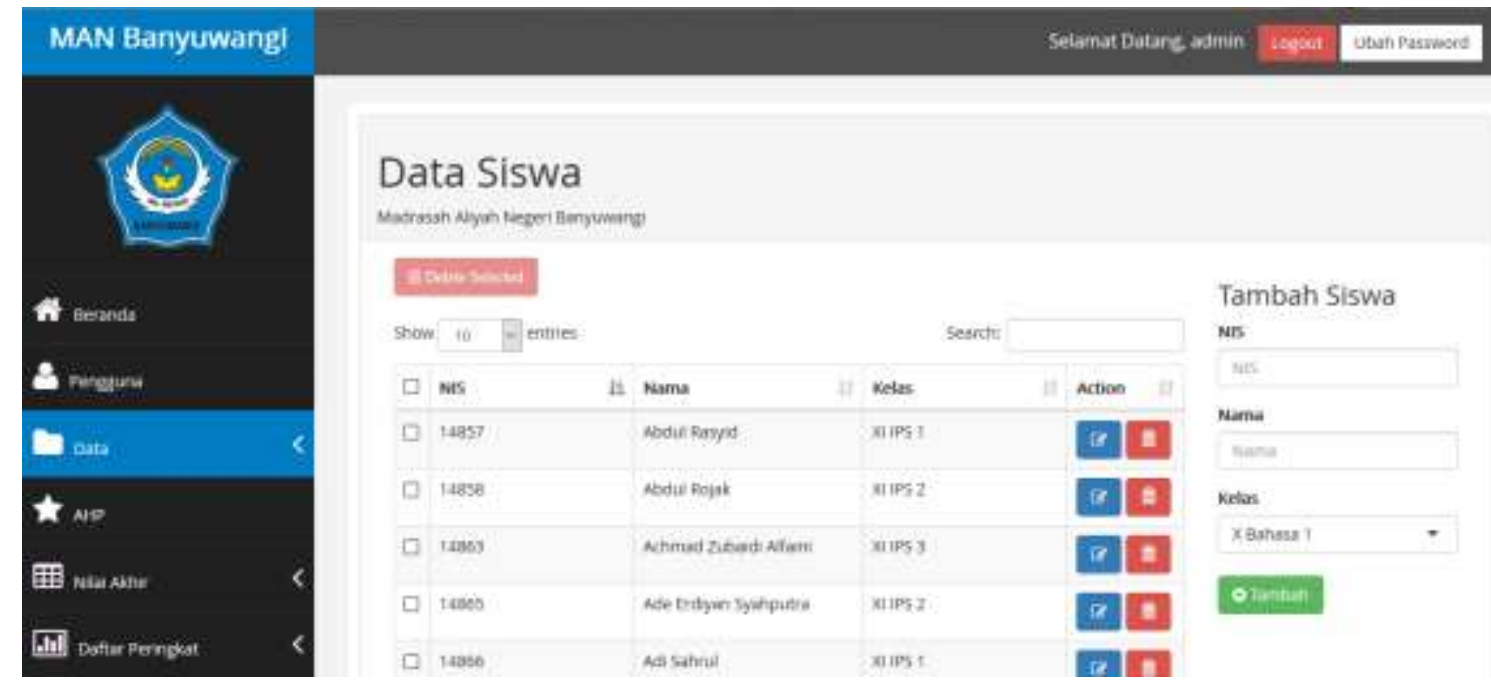

Figure 8. DISPLAY STUDENT DATA

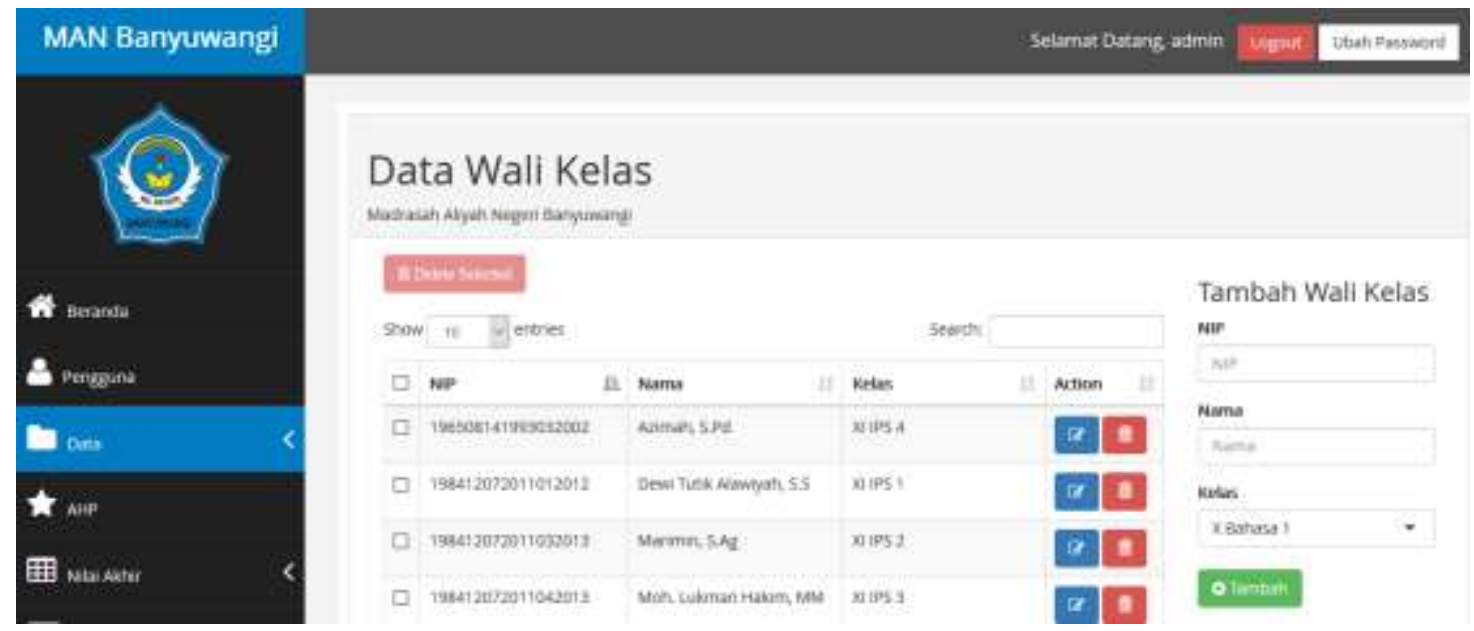

Figure 9. CLASS GUARDIAN DATA VIEWS

AHP display is a menu for processing student grades that have been entered by the homeroom teacher using the AHP method as in Figure 10.

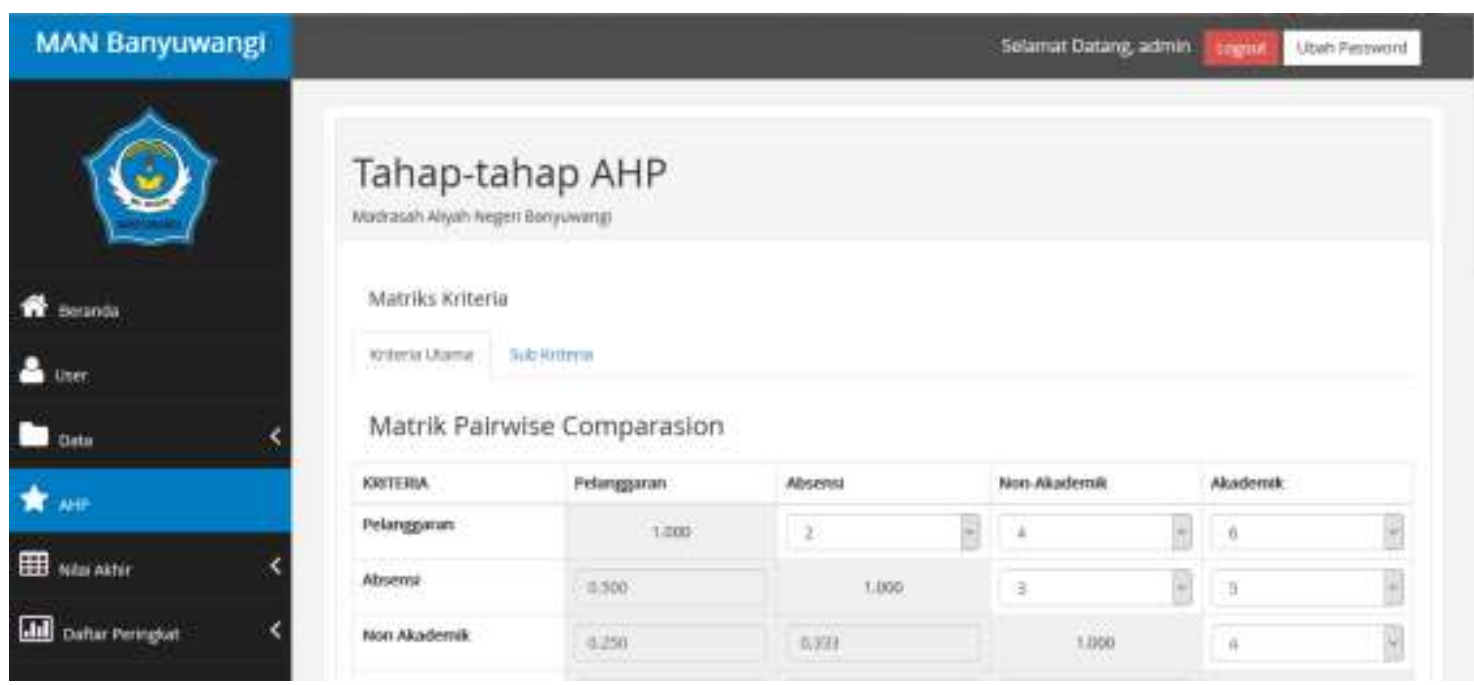

102 INTENSIF: Jurnal Ilmiah Penelitian dan Penerapan Teknologi Sistem Informasi 
INTENSIF, Vol.4 No. 1 February 2020

ISSN: 2580-409X (Print) / 2549-6824 (Online)

DOI: https://doi.org/10.29407/intensif.v4i1.13769

\section{Figure 10. AHP DISPLAY}

In Figure 10, there are value criteria used to determine student rankings following the method used, the AHP method. Here the criteria used are determined in advance following the provisions in the AHP. All grades used in the AHP process are entered first by each homeroom teacher in the form of violations, absences, non-academic values, and academic values, as shown in Figure 11. The system then converts these values following Table 3.

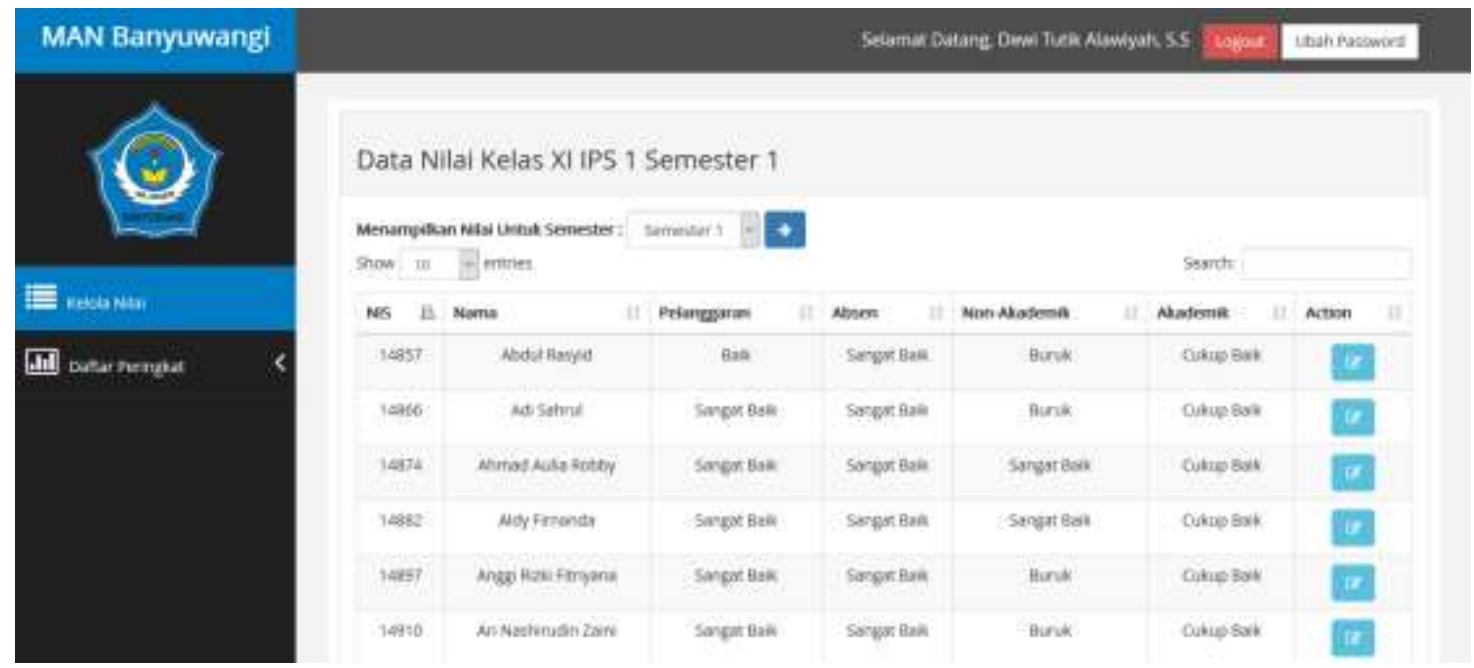

Figure 11. PAGE MANAGE VALUE

The system then performs the results of the AHP calculation of all the criteria according to the AHP flowchart in Figure 2, and the results can be seen on the final value page shown in Figure 12. On this page, the value of each AHP process result criteria for all students is displayed. Furthermore, the amount will be multiplied by the criteria weight to get the final value which is then sorted to get the ranking, as shown in Figure 13.

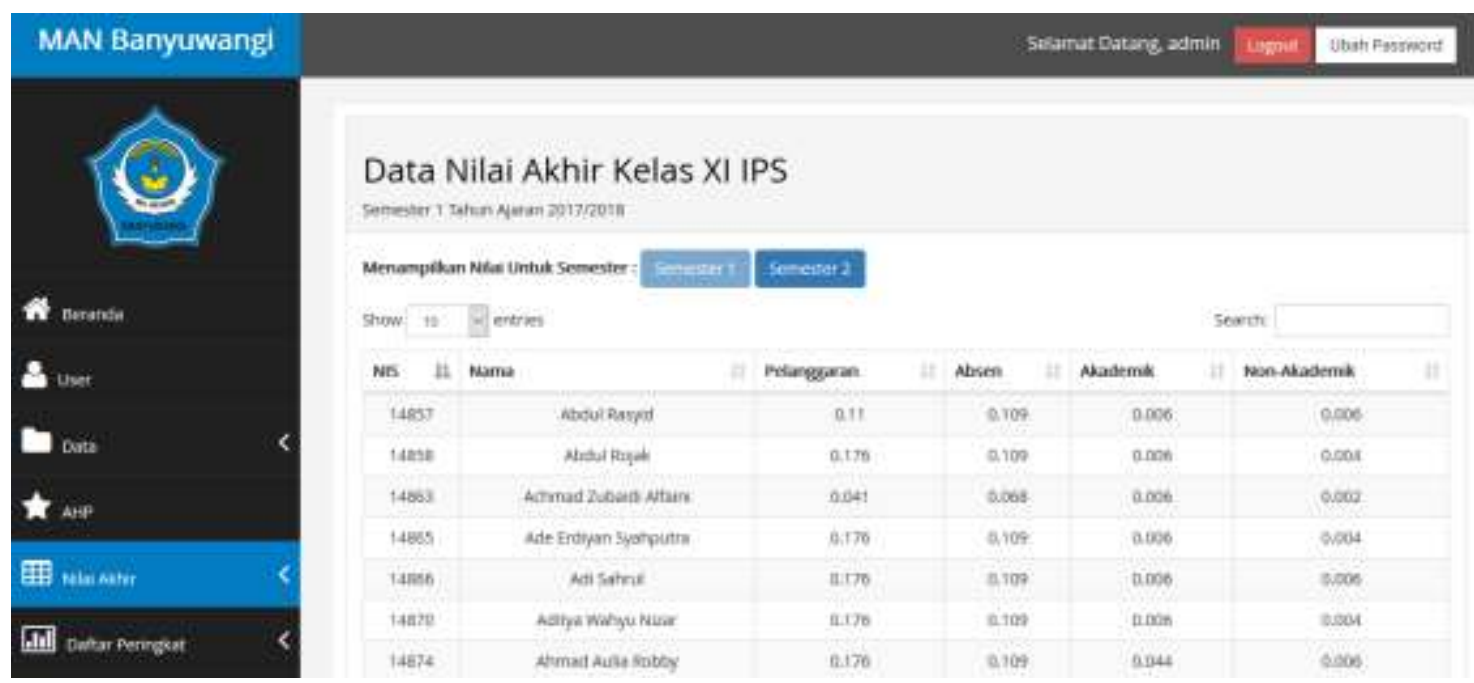

INTENSIF: Jurnal Ilmiah Penelitian dan PenerapanTeknologi Sistem Informasi 
INTENSIF, Vol.4 No.1 February 2020

ISSN: 2580-409X (Print) / 2549-6824 (Online)

DOI: https://doi.org/10.29407/intensif.v4i1.13769

\section{Figure 12. LOOK AT THE END VALUE EVERY CRITERION}

Ranking list display is a student ranking list display from the results of the value processing process, which is shown in Figure 13. Each student can see the ranking of the AHP ranking according to their respective majors. To be able to see it, students enter the username and password that they have on the user's login page.
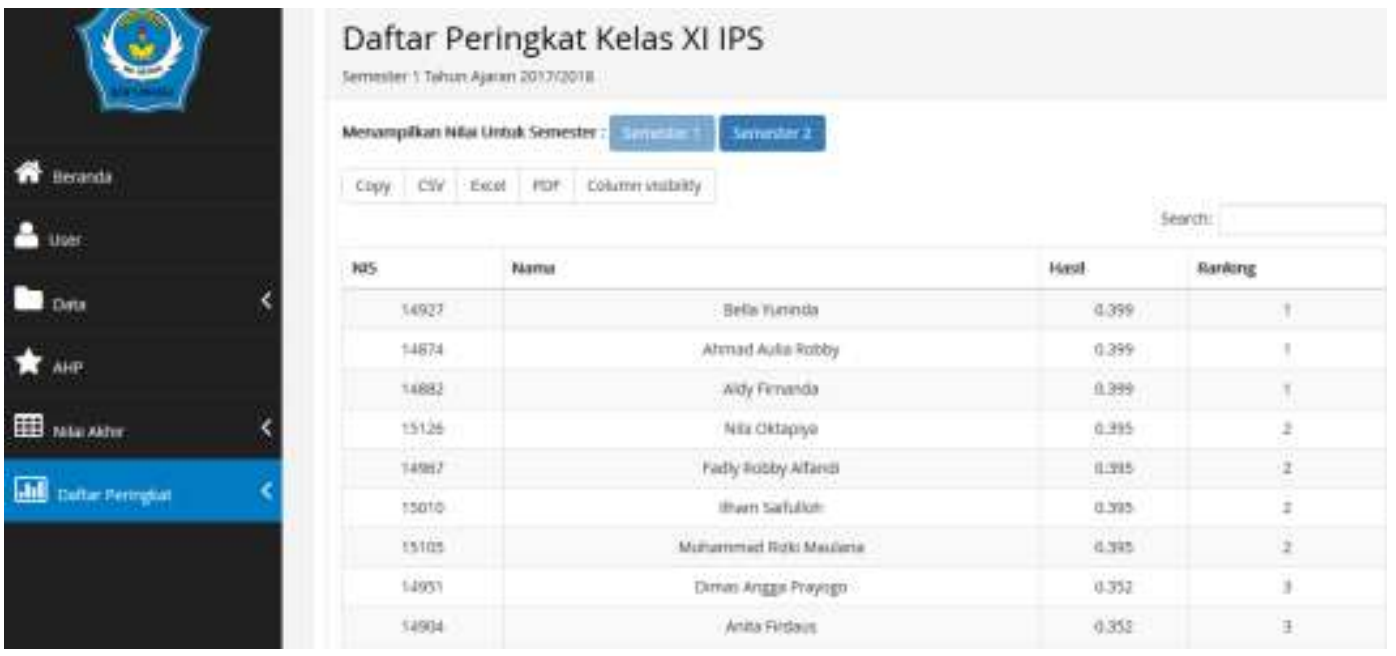

Figure 13 DISPLAY RANK LIST

\section{System Testing}

System testing is an important thing to do to find out whether the system made runs according to its function or not [18]. The method used by the author is black box testing that is testing carried out by observing the results of system operation. Blackbox test results are in Table 13.

Table 13. BLACK BOX TESTING RESULTS

\begin{tabular}{llll}
\hline \hline \multicolumn{1}{c}{ Test Case } & \multicolumn{1}{c}{ Which is expected } & \multicolumn{1}{c}{ Observation } & Status \\
\hline Login Admin & Can enter the main admin page display & $\begin{array}{l}\text { Can open the main admin page } \\
\text { display }\end{array}$ & $\begin{array}{l}\text { Corresp } \\
\text { onding }\end{array}$ \\
\hline Add class data & Displays a form for entering class data & Class data is added and stored & $\begin{array}{l}\text { Corresp } \\
\text { onding }\end{array}$ \\
\hline Add student data & $\begin{array}{l}\text { Displays a form for entering student } \\
\text { data }\end{array}$ & $\begin{array}{l}\text { Student data is increased } \\
\text { stored }\end{array}$ & $\begin{array}{l}\text { Cond } \\
\text { onding }\end{array}$ \\
\hline $\begin{array}{l}\text { Add homeroom } \\
\text { data }\end{array}$ & $\begin{array}{l}\text { Displays a form for entering homeroom } \\
\text { data }\end{array}$ & $\begin{array}{l}\text { Homeroom data is added } \\
\text { stored }\end{array}$ & $\begin{array}{l}\text { Corresp } \\
\text { onding }\end{array}$ \\
\hline Change class data & $\begin{array}{l}\text { Display the form change class data and } \\
\text { save data changes }\end{array}$ & $\begin{array}{l}\text { Data changes according to the } \\
\text { actual data }\end{array}$ & $\begin{array}{l}\text { Corresp } \\
\text { onding }\end{array}$ \\
\hline $\begin{array}{l}\text { Change student } \\
\text { data }\end{array}$ & $\begin{array}{l}\text { Displays form change student data and } \\
\text { save data changes }\end{array}$ & $\begin{array}{l}\text { Data changes according to the } \\
\text { actual data }\end{array}$ & $\begin{array}{l}\text { Corresp } \\
\text { onding }\end{array}$ \\
\hline $\begin{array}{l}\text { Change homeroom } \\
\text { data }\end{array}$ & $\begin{array}{l}\text { Displays the data form of the homeroom } \\
\text { teacher and saves the data changes }\end{array}$ & $\begin{array}{l}\text { Data changes according to the } \\
\text { actual data }\end{array}$ & $\begin{array}{l}\text { Corresp } \\
\text { onding }\end{array}$ \\
\hline Add user data & Displays a form for entering user data & User data is added and stored & Corresp \\
\hline
\end{tabular}

104 INTENSIF: Jurnal Ilmiah Penelitian dan Penerapan Teknologi Sistem Informasi 
INTENSIF, Vol.4 No.1 February 2020

ISSN: 2580-409X (Print) / 2549-6824 (Online)

DOI: https://doi.org/10.29407/intensif.v4i1.13769

\begin{tabular}{|c|c|c|c|}
\hline & & & onding \\
\hline Change user data & $\begin{array}{l}\text { Display the form change user data and } \\
\text { save data changes }\end{array}$ & $\begin{array}{l}\text { Data changes according to the } \\
\text { actual data }\end{array}$ & $\begin{array}{l}\text { Corresp } \\
\text { onding }\end{array}$ \\
\hline AHP Process & $\begin{array}{l}\text { Entering the weight of the assessment in } \\
\text { each student's criteria }\end{array}$ & Data stored and processed & $\begin{array}{l}\text { Corresp } \\
\text { onding }\end{array}$ \\
\hline The final value & $\begin{array}{l}\text { Displays the results of the student's final } \\
\text { grade }\end{array}$ & Showing final results & $\begin{array}{l}\text { Corresp } \\
\text { onding }\end{array}$ \\
\hline $\begin{array}{l}\text { Enter student } \\
\text { grades }\end{array}$ & $\begin{array}{l}\text { Homeroom teachers enter student } \\
\text { grades }\end{array}$ & $\begin{array}{l}\text { Student grades that have been } \\
\text { entered by the homeroom teacher } \\
\text { will be entered into the ranks on } \\
\text { the system. }\end{array}$ & $\begin{array}{l}\text { Corresp } \\
\text { onding }\end{array}$ \\
\hline $\begin{array}{l}\text { Change student } \\
\text { grades }\end{array}$ & $\begin{array}{l}\text { Homeroom teacher changes student } \\
\text { grades }\end{array}$ & $\begin{array}{l}\text { Student grades that have been } \\
\text { altered by the homeroom teacher } \\
\text { will be entered into the ranks on } \\
\text { the system. }\end{array}$ & $\begin{array}{l}\text { Corresp } \\
\text { onding }\end{array}$ \\
\hline
\end{tabular}

Testing several aspects of the application to users is also done to all system users according to the level of access rights, including admin (administrative staff), homeroom teacher, and students. After the user uses the system, they are asked to rate the system through a questionnaire based on ISO 9126 [19]. The results of the questionnaire gave a final value of $92.29 \%$, which was well received by the user, as in Table 14 .

Table 14. USER QUESTIONARY RESULTS

\begin{tabular}{|c|c|c|}
\hline No & Aspect & $\begin{array}{c}\text { Average } \\
\text { value }\end{array}$ \\
\hline 1 & Functionality & $90,96 \%$ \\
\hline 2 & Reliability & $85,60 \%$ \\
\hline 3 & Usability & $96,60 \%$ \\
\hline 4 & Efficiency & $96,00 \%$ \\
\hline & Average total & $92,29 \%$ \\
\hline
\end{tabular}

\section{CONCLUSIONS AND RECOMMENDATIONS}

In this study, a parallel class ranking model has been developed using the Analytic Hierarchy Process (AHP) method with multiple criteria in Banyuwang State Aliyah Madrasah by using four criteria, namely academic grades, non-academic values, violation scores, and absenteeism. The system is built on a web-based and has been tested using the black box testing method with relevant results, and the results of the user questionnaire obtained $92.29 \%$ of the system can be well received. The system can be completed by displaying graphs of the development of student achievement each semester.

\section{ACKNOWLEDGEMENT}

The author would like to thank the Banyuwangi State Polytechnic Research and Community Service Center for providing financial support to this research.

INTENSIF: Jurnal Ilmiah Penelitian dan PenerapanTeknologi Sistem Informasi 
DOI: https://doi.org/10.29407/intensif.v4i1.13769

\section{REFERENCES}

[1] A. Majid, Perencanaan Pembelajaran Mengembangkan Standar Kompetensi Guru, 7th ed. Bandung: Rosda, 2011.

[2] S. Arikunto, Dasar - Dasar Evaluasi Pendidikan, 3rd ed. Jakarta: Bumi Aksara, 2019.

[3] E. Thanassoulis, P. K. Dey, K. Petridis, I. Goniadis, and A. C. Georgiou, "Evaluating higher education teaching performance using combined analytic hierarchy process and data envelopment analysis," J. Oper. Res. Soc., 2017.

[4] R. Radhakrishnan and A. Kalaichelvi, "Selection Of The Best School For The Children A Decision Making Model Using Extent Analysis Method On Fuzzy Analytic Hierarchy Process," Int. J. Innov. Res. Sci. Eng. Technol., vol. 3, no. 5, pp. 12334-12344, 2014.

[5] A. R. Mamat et al., "Preschool selection system using Analytic Hierarchy Process (AHP): Implementation and usability study," in Proceedings - 2017 IEEE 2nd International Conference on Automatic Control and Intelligent Systems, I2CACIS 2017, 2017.

[6] G. Gestiada, A. Nazareno, and R. M. Roxas-Villanueva, "Development of a senior high school career decision tool based on social cognitive career theory," Philipp. J. Sci., 2017.

[7] T. D. Puspitasari, E. O. Sari, P. Destarianto, and H. Y. Riskiawan, "Decision Support System for Determining Scholarship Selection using an Analytical Hierarchy Process," in Journal of Physics: Conference Series, 2018.

[8] Marfuah and S. Widiantoro, "The Implementation of Analytical Hierarchy Process Method for Outstanding Achievement Scholarship Reception Selection at Universal University of Batam," in IOP Conference Series: Earth and Environmental Science, 2017.

[9] Frieyadie and S. M. Ramadhan, "Penerapan Metode AHP Untuk Membantu Siswa Memilih Jurusan Yang Tepat Di SMK," J. Rekayasa Sist. Dan Teknol. Inf., vol. 2, no. 3, 2018.

[10] B. Basri, S. Syarli, and F. Febryatnti, "Multi-Attribute Analysis With AHP Algorithm to Optimize Student Ranking Recommendation in Educational Process," in International Conference Research on Education, Social, Science and Technology (CREST) 2018, 2018.

[11] R. S. Pressman, Software Engineering: A Practitioner's Approach, 7th ed. New York: McGraw-Hill, 2010.

[12] Y. Bassil, "A Simulation Model for the Waterfall Software Development Life Cycle," Int. J. Eng. Technol., vol. 2, no. 5, 2012.

[13] Z. Hasibuan, Metodologi Penelitian Pada Bidang Ilmu Komputer dan Teknologi Informasi. Jakarta: Penerbit Erlangga, 2007.

[14] T. Saaty and L. Vargas, Models, methods, concepts \& applications of the analytic hierarchy process. New York: Springer, 2012.

[15] H. H. Inès and F. Ben Ammar, "AHP multicriteria decision making for ranking life cycle assessment software," in 2015 6th International Renewable Energy Congress (IREC),

106 INTENSIF: Jurnal Ilmiah Penelitian dan Penerapan Teknologi Sistem Informasi 
INTENSIF, Vol.4 No.1 February 2020

ISSN: 2580-409X (Print) / 2549-6824 (Online)

DOI: https://doi.org/10.29407/intensif.v4i1.13769

2015.

[16] R. A. Sukamto and M. Shalahuddin, Rekayasa Perangkat Lunak. Bandung: Informatika, 2014.

[17] D. H. Kusuma, M. N. Shodiq, D. Yusuf, and L. Saadah, "Si-Bidan: Sistem Informasi Kesehatan Ibu dan Anak," INTENSIF J. Ilm. Penelitian dan Penerapan Teknol. Sist. Inf., vol. 3, no. 1, 2019.

[18] S. Nidhra, "Black Box and White Box Testing Techniques - A Literature Review," Int. J. Embed. Syst. Appl., 2012.

[19] G. Wang, D. Y. Bernanda, J. F. Andry, A. Nurul Fajar, and Sfenrianto, "Application Development and Testing Based on ISO 9126 Framework," in Journal of Physics: Conference Series, 2019. 